\title{
Limitations in Adjuvant Breast Cancer Therapy: The Predictive Potential of Pharmacogenetics and Pharmacogenomics
}

\author{
Patrick Thurner Christian Nanoff \\ Institute of Pharmacology, Medizinische Universität Wien, Austria
}

\author{
Key Words \\ Adjuvant breast cancer therapy - Tamoxifen resistance . \\ Sensitivity to taxane treatment . Pharmacokinetics \\ of antihormonal agents - Pharmacogenomics of \\ cytostatic drugs
}

\section{Summary}

Adjuvant therapy improves survival in breast cancer patients. However, both antihormonal agents and cytostatic chemotherapy meet with variable success. We have searched the literature for biological causes of variability in drug response. Evidence suggests that additional markers may be introduced because of their potentially predictive value in adjuvant therapy: i) overexpression of epidermal growth factor receptor is likely inversely correlated to the sensitivity to estrogen antagonists; ii) presence of the GAB2 adaptor protein and of the ABCC3 and mdr-1 efflux pumps modulates taxane sensitivity in HER2-positive breast cancer; and iii) CYP2D6 genotyping should be a routine measure to avoid failure of tamoxifen treatment. In contrast, there is little in the way of genetic evidence for differences in the pharmacokinetics of other antihormonal or cytostatic drugs. Nevertheless, genotypes may affect efficacy and toxicity of cytostatic drugs (e.g. doxorubicin), but this evidence has to be confirmed by prospective trials.
Schlüsselwörter

Adjuvante Behandlung von Brustkrebspatientinnen . Tamoxifen-Resistenz · Empfindlichkeit für Behandlung mit Taxanen - Pharmakokinetische Parameter von Hormonantagonisten · Pharmakogenomik der Zytostatika

\section{Zusammenfassung}

Die Prognose von Patientinnen mit Brustkrebs wurde durch Fortschritte bei der adjuvanten Therapie an sich besser, wobei sowohl in der Behandlung mit Hormonantagonisten als auch in der zytostatischen Therapie NonResponders häufig vorkommen. In der Literatur finden sich Hinweise auf mögliche biologische Ursachen für variable Wirksamkeit. Dementsprechend könnten folgende Biomarker wegen ihres potentiellen prädiktiven Aussagewerts für den Erfolg adjuvanter Therapie ausschlaggebend sein: i) Überexpression des epidermalen Wachstumsfaktorrezeptors, die invers mit Tumorempfindlichkeit für Östrogenantagonisten korreliert; ii) die Effluxpumpen P-Glykoprotein und $\mathrm{ABCC} 3$ sowie das Adaptorprotein GAB2, die die Wirkung von Taxan-Zytostatika in HER2-positivem Brustkrebs beeinflussen; (iii) das CYP2D6 Gen, durch dessen Typisierung Tamoxifen-NonResponders identifiziert werden können. Im Übrigen sind genetische Polymorphismen mit Bedeutung für die pharmakokinetischen Eigenschaften von Hormonantagonisten bzw. Zytostatika nicht bekannt. Individuelle Genotypen vermögen aber Effekt und Toxizität einzelner Zytostatika (z.B. von Doxorubicin) zu steigern, wobei dieser wie auch die oben erwähnten Befunde erst in prospektiven, randomisierten Studien validiert werden müssen.

\begin{tabular}{ll}
\hline KARGER & ( ) 2008 S. Karger GmbH, Freiburg \\
Fax +497614520714 & Accessible online at: \\
Information@Karger.de & www.karger.com/brc \\
www.karger.com &
\end{tabular}




\section{Introduction}

Breast cancer is the most prevalent malignant tumor in women. Along with the introduction of new therapies and advances in diagnostics, mortality is declining, while the incidence has been on the rise: The rate of newly diagnosed diseases increased by $3 \%$ during the past decade; refraining from hormone replacement therapy in postmenopausal women will probably stop the trend [1]. A major therapeutic advance is in slowing tumor recurrence using adjuvant treatment. To assist physicians in predicting the treatment response, a scientific focus has been directed at the generation and evaluation of biomarkers (e.g. measuring hormone and growth factor receptors in tumor tissue). Since DNA sequencing has been established as a routine laboratory procedure, genetic variables that could impinge on the treatment response are being assessed.

Pharmacogenetics and pharmacogenomics both refer to the grounds of interindividual differences in drug efficacy and tolerability. Pharmacogenetics mostly encompasses genetically determined differences in uptake, distribution, and disposal of a drug; pharmacogenomics strives to account for differences in drug response by correlating it to the expression of drug targets. The goal is to minimize the risk of side effects, and to identify patients with intrinsic resistance to commonly prescribed drugs so that an alternative drug can be selected. In principle, breast cancer is amenable to pharmacogenomic testing; many genetic variants within the tumor are stable since most tumor DNA was found to be the germline DNA of the patient [2]. Thus, treatment-predictive traits should also reside in the individual germline genome.

\section{Drugs Commonly Used in Adjuvant Therapy}

\section{Cytostatic Drugs}

The use of adjuvant therapy, i.e. systemic therapy after local management of breast cancer, substantially improves survival in patients who are at risk of relapse. In adjuvant chemotherapy, most comparisons show little difference between regimens (commonly employed cytostatic drugs are given in table 1). Advantages have been reported for regimens containing the anthracycline doxorubicin as well as for the subsequent use of taxanes (paclitaxel and docetaxel) following treatment with doxorubicin/cyclophosphamide.

Table 1 shows that genetic polymorphisms impinge on effect and tolerability of cytostatic drugs. Of note, genetic differences hardly affect pharmacokinetics; they rather seem to direct the drug effect. This is obvious in the case of 5-fluorouracil (5-FU) and methotrexate (MTX) where the cellular effect is linked to the enzymatic activity of the identified gene products. The cellular action of anthracyclines has long been suggested to rely on the formation of reactive oxygen species, and the role of the implicated oxidases possibly is in their detoxification. The variability in anthracycline and taxane sensitivity due to geno- type-dependent activity of NAD(P)H oxidases and a CYP1B1 polymorphism (CYP1B1 is involved in mammary estrogen metabolism), respectively, needs to be confirmed.

\section{Drugs Used to Block the Effect of Estrogen}

Aromatase inhibitors, the selective estrogen receptor modulators (SERMs), and the pure estrogen antagonist fulvestrant are subject to metabolic degradation; elimination of the active compounds has been shown to be independent of kidney function. Because of an extended residency time and a rather large volume of distribution, steady-state plasma levels are achieved with delay (table 2).

It appears unsettling that the SERM raloxifene has been described as an irreversible inhibitor of the $3 \mathrm{~A}$ isoforms of the CYP450-dependent monooxygenases (CYP 3A4/5), which might suggest the potential of deleterious drug interactions with other CYP3A substrates (e.g. lipid lowering agents). However, we found only 1 case report suggestive of a pharmacokinetic drug interaction [3]. The reason that raloxifene apparently has not caused more incidents of harmful interaction is likely due to the high concentrations required for CYP450 blockage $(>1 \mu \mathrm{mol} / \mathrm{l})$ relative to the ambient plasma concentration $(<1 \mathrm{nmol} / \mathrm{l})$.

The SERM tamoxifen is converted into active metabolites. The conversion requires CYP3A4/5 (demethylation) and CYP2D6 (hydroxylation) to give 4-hydroxy-N-desmethyl-tamoxifen (endoxifen). While both metabolites have more than 10-fold higher potency than tamoxifen to suppress estrogen-mediated actions, only endoxifen accumulates to high levels in the body. It is therefore believed that endoxifen represents the active principle of tamoxifen.

CYP2D6 is an example of a highly polymorphic gene. The different alleles can combine to result in variable enzymatic activities ranging from none to very high [4]. Very likely, the consequences of the CYP2D6 gene polymorphism bear out on the efficacy of tamoxifen in suppressing disease progression in breast cancer patients indicating that CYP2D6 is crucial in tamoxifen biotransformation [5, 6]. Thus, genotyping the CYP2D6 alleles to identify individuals that have no enzymatic CYP2D6 activity may be useful in avoiding tamoxifen treatment failure. Along the same line, concomitant use of drugs that inhibit CYP2D6 activity should be avoided (table 3) [7]. There is little doubt that several if not all of the anti-estrogen drugs have reduced levels if taken concurrently with compounds that induce CYP450-dependent enzymatic processes (such as rifampicin, carbamazepine, phenytoin, nevirapin); hence their effectiveness becomes uncertain, and this has also to be suspected for tamoxifen.

\section{Resistance to Tamoxifen Treatment}

The traditional mainstay of antihormonal therapy is tamoxifen, an estrogen antagonist that binds to both nuclear estro- 
Table 1. Genetic polymorphisms and drug interactions concerning standard cytostatic drugs

\begin{tabular}{|c|c|c|c|c|c|}
\hline \multirow[t]{2}{*}{ Compound } & \multicolumn{3}{|c|}{ Gene polymorphisms assessed [Ref.] } & \multirow{2}{*}{$\begin{array}{l}\text { Pharmacokinetic drug } \\
\text { interaction [Ref.] }\end{array}$} & \multirow[t]{2}{*}{ Impact } \\
\hline & Positive association & Impact & No association & & \\
\hline Cyclophosphamide & CYP2C19 [32] & half-life varies by $30 \%$ & $\begin{array}{l}\text { CYP(3A4/5, 2B6, } \\
\text { 2C9), GSTP1, } \\
\text { ALDH(1.2) [33] }\end{array}$ & $\begin{array}{l}\text { aprepitant, a CYP3 } \\
\text { A4 inhibitor [34] }\end{array}$ & negligible \\
\hline Methotrexate & $\begin{array}{l}\text { dihydrofolate } \\
\text { reductase SNPs } \\
(829 \mathrm{C}, 1610 \mathrm{C}, 317 \mathrm{~A}) \\
{[35,36]}\end{array}$ & drug resistance & - & $\begin{array}{l}\text { drugs inhibiting renal } \\
\text { elimination (e.g. non- } \\
\text { steroidal anti- } \\
\text { inflammatory drugs, } \\
\text { tetracyclines) }\end{array}$ & $\begin{array}{l}\text { increase in half-life } \\
\text { and toxicity }\end{array}$ \\
\hline 5-Fluorouracil & MTHFR (A1298) & drug resistance [37] & DPYD [38] & $\begin{array}{l}\text { brivudin, sorivudin: } \\
\text { inhibitors of DPD [39] }\end{array}$ & increased toxicity \\
\hline Paclitaxel, docetaxel & CYP1B1 & $\begin{array}{l}\text { CYP1B1*3 allele } \\
\text { enhances cytostatic } \\
\text { response and toxicity } \\
{[40]}\end{array}$ & $\begin{array}{l}\text { CYP(2C8, 3A4, 3A5), } \\
\text { ABC(B1, G2, C1, C2) } \\
{[41,42], \text { SLCO1B3 }} \\
{[43]}\end{array}$ & aprepitant & negligible \\
\hline \multirow[t]{2}{*}{$\begin{array}{l}\text { Anthracylines } \\
\text { (e.g. doxorubicin) }\end{array}$} & $\begin{array}{l}\text { NAD }(\mathrm{P}) \mathrm{H} \text { oxidases } \\
\left(\mathrm{NQO} 1{ }^{*}\right) 2[44]\end{array}$ & drug resistance & - & - & - \\
\hline & NCF4, p22phox [45] & cardiotoxicity & - & - & - \\
\hline
\end{tabular}

CYP = Cytochrome P450-dependent monooxgenase or encoding gene; ALDH = aldehyde dehydrogenase; SNP = single nucleotide polymorphism; MTHFR = methylene tetrahydrofolate reductase; DPYD = gene coding for DPD; DPD = dihydropyrimidine dehydrogenase; ABC = ATP-binding cassette transporter or encoding gene; NCF4 = neutrophil cytosolic factor 4, a cytosolic component of NADPH-oxidase; p22phox = light chain of cytochrome $\mathrm{b}(-245)$ which is a component of the NADPH oxidase (NOX) complex responsible for the respiratory burst in phagocytes.

Table 2. Pharmacokinetic properties of commonly used antiestrogen drugs

\begin{tabular}{|c|c|c|c|c|c|}
\hline \multirow[t]{2}{*}{ Drug } & \multicolumn{5}{|c|}{ Pharmacokinetic properties [Ref.] } \\
\hline & $\begin{array}{l}\text { Enzymatic clearance } \\
\text { by }\end{array}$ & Half-life & $\begin{array}{l}\text { Volume of } \\
\text { distribution }\end{array}$ & $\begin{array}{l}\text { Time to } \\
\text { equilibrium }\end{array}$ & Specifics \\
\hline Exemestane & CYP3A4 & $24 \mathrm{~h}$ & $>20$ 1/kg [46] & 7 days $[47]$ & $\begin{array}{l}\text { androgenic } \\
\text { metabolite }\end{array}$ \\
\hline Letrozole & CYP3A4,2A6 & 2 days & $21 / \mathrm{kg}$ & 2-6 weeks & inhibits CYP2A6 \\
\hline Anastrozole & $\begin{array}{l}\text { N-dealkylation, } \\
\text { hydroxylation, } \\
\text { glucuronidation [47] }\end{array}$ & $2-3$ days & not published & 7 days & $\begin{array}{l}\text { inhibition of CYP } \\
\text { activity is } \\
\text { negligible [48] }\end{array}$ \\
\hline Tamoxifen & $\begin{array}{l}\text { CYP3A, 2D6, (2C9) } \\
\text { [49], conjugated to } \\
\text { glucuronic acid/ } \\
\text { sulphuric acid }\end{array}$ & $\begin{array}{l}\text { 5-7 days } \\
\text { (metabolite }= \\
14 \text { days) }\end{array}$ & $5 \mathrm{l} / \mathrm{kg}$ & 4 weeks & $\begin{array}{l}\text { 4-hydroxy-N- } \\
\text { desmethyl-tamoxifen } \\
=\text { endoxifen = active }\end{array}$ \\
\hline Raloxifene & $\begin{array}{l}\text { CYP3A, UGT1A10 } \\
\text { [50] }\end{array}$ & $\begin{array}{l}\text { approximately } \\
40 \mathrm{~h}\end{array}$ & $2,3001 / \mathrm{kg}$ & $\begin{array}{l}\text { estimated to } \\
\text { be } 1-2 \text { weeks }\end{array}$ & $\begin{array}{l}\text { inactivates CYP3A } \\
\text { [51] }\end{array}$ \\
\hline Fulvestrant & $\begin{array}{l}\text { extensive metabolism, } \\
\text { CYP3A4 involved [52] }\end{array}$ & $\begin{array}{l}\text { approximately } \\
40 \text { days }\end{array}$ & $\begin{array}{l}\operatorname{large} \\
(>1001 / \mathrm{kg})[52]\end{array}$ & $\begin{array}{l}\text { after 3-6 doses } \\
\text { ( = 3-6 months) }\end{array}$ & $\begin{array}{l}\text { i.m. way of } \\
\text { administration }\end{array}$ \\
\hline
\end{tabular}

CYP = Cytochrome P450-dependent monooxgenase or encoding gene; UGT = UDP-glucuronyl transferase. gen receptor (ER) subtypes and in some tissues exerts estrogen-like effects. Although aromatase inhibitors have a somewhat improved efficacy and although there are fewer adverse events in postmenopausal women (risk of venous thromboembolism and endometrial cancer), tamoxifen is still the antihormonal treatment of choice in premenopausal patients who apparently evade the increased risk of endometrial cancer or blood clots $[8,9]$. Despite the benefit of tamoxifen in patients with all stages of ER-positive breast cancer, a major obstacle to its use is treatment resistance which either occurs de novo or is later acquired after initial benefit. However, we are at a loss to predict the individual risk of intrinsic or acquired tamoxifen resistance in patients with ER-positive cancers (approximately $20 \%$ with $\mathrm{ER}^{+} /$progesterone receptor $(\mathrm{PR})^{+}$tumors and approximately $60 \%$ with $\mathrm{ER}^{+} / \mathrm{PR}^{-}$tumors) - with the exception of a risk due to the inability to metabolize tamoxifen (see above). 
Table 3. Inhibitors of CYP2D6 enzymatic activity

\begin{tabular}{llll}
\hline Class [Ref.] & & & \\
\hline Antidepressants & $\begin{array}{l}\text { Quinine } \\
\text { compounds }\end{array}$ & Antipsychotics & Miscellaneous \\
\hline $\begin{array}{l}\text { fluoxetine } \\
\text { paroxetine } \\
\text { fluvoxamine }\end{array}$ & $\begin{array}{l}\text { chloroquin } \\
\text { sertraline } \\
\text { bupropion [55] }\end{array}$ & $\begin{array}{l}\text { haloperidol } \\
\text { thioridazine } \\
\text { chlorpromazine } \\
\text { perphenazine }\end{array}$ & $\begin{array}{l}\text { cinacalcet [53] (calcimimetic) } \\
\text { amiodarone (antiarrhythmic) } \\
\text { propafenone (antiarrhythmic) } \\
\text { terbinafine [54] (antifungal) } \\
\text { ticlopidin (platelet inhibitor) }\end{array}$ \\
\hline
\end{tabular}

\section{Evidence for a Specific Effect of Growth Factor Receptors in Tamoxifen Resistance}

There are a number of concepts to account for the cellular mechanism leading to tamoxifen resistance [10]: i) ER hypersensitivity that is an ER not inhibited but activated by tamoxifen; ii) overexpression of growth factor receptors; iii) enhanced activity of protein kinases that are constituents of signaling pathways (ERK1/2, AKT, Src); and iv) deregulated expression of components controlling the cell cycle (cyclins D and E; p21, p27). These putative risk factors have been identified in recurrent cancers and/or by reconstituting tamoxifen resistance through genetic engineering of cancer cells in vitro. A fundamental problem is to distinguish alterations that are causative in initiating resistance from those that represent a selective growth advantage in an a priori resistant cell. It may be misleading to claim importance for a risk factor suggesting it may be used as a clinical marker if it belongs to the phenotype of a cancer cell that has originated from a malignant clone. Rather, any genetic or protein expression signature needs to be validated in a prospective trial possibly within the adjuvant setting.

It has long been suggested that high levels of growth factor receptors, specifically epidermal growth factor receptor (EGFR; ErbB1/HER1), are predictive for tamoxifen resistance. The EGFR family comprises among others ErbB1/ EGFR and ErbB2 (HER2/neu). Receptor activation promotes mitogenic signaling through Ras/ERK and possibly other kinases, thus increasing the cell proliferation rate. The argument for an important role in tamoxifen resistance is that growth factor receptor signaling can induce ER hypersensitivity (via ER phosphorylation or by regulating transcriptional coactivators such as AIB1) [11].

While ErbB2/HER2 is established as pharmacogenomic marker in breast cancer, measuring EGFR has met with technical difficulties and its use as a marker was considered problematic. Recently, an assessment of EGFR expression has been carried out in tumor tissue from patients enrolled in a long-term clinical trial of tamoxifen efficacy. The results substantiated the assumption that EGFR expression is associated with tamoxifen resistance [12]. The significance of the finding however needs to be confirmed.

\section{Role of a Hypersensitive Estrogen Receptor in Promoting Malignancy}

While it is clear that growth factor signaling can stimulate cell proliferation in breast cancer, it may lead to additional effects that require ER expression. Firstly, a hypersensitive ER may interfere with breast cancer recognition by immune cells [13], and secondly, growth factors can enhance the ability of a tumor to form blood vessels. The arguments supporting the latter are summarized as follows: i) growth factor receptors are known to mediate induction of the angiogenic vascular endothelial growth factor (VEGF) in cells from various tumors $[14,15]$ including breast cancer [16]; ii) there is a correlation between VEGF expression and microvessel density in primary breast cancer sections [17]; iii) estradiol or tamoxifen can increase VEGF mRNA and protein expression [18], and estrogen deprivation has been shown to reduce vascularization of breast cancer xenografts [19]; a VEGF increase due to tamoxifen was also detected in the blood of breast cancer patients suggesting that a hypersensitive ER is involved [20]; iv) if VEGF-mediated angiogenesis were important for the progression of breast cancer, anti-VEGF treatment should be effective in controlling the disease; this seems to be the case [21].

The purported mechanisms by which ER hypersensitivity can confer tamoxifen resistance also highlight the risks associated with hormone replacement therapy; the foremost effect of exogenous estradiol will be in promoting latent cancer if a hypersensitive ER is indeed relevant for progression of the disease. The reported decrease in breast cancer incidence following a fall in the use of hormone replacement therapy is an expected corollary [1]. Conversely, the clinical effectiveness of reducing estrogen synthesis by use of aromatase inhibitors further supports the concept that a hypersensitive receptor can be activated by weak stimuli such as low postmenopausal estrogen levels. Aromatase inhibitors suppress breast cancer progressing under tamoxifen; however many patients do not respond. While resistance to aromatase inhibitors may rest on similar cellular alterations as tamoxifen resistance (growth factor signaling, hypersensitive ER), additional characteristics are not clear [22]. 


\section{Variable Resistance of HER2-Positive Breast Cancer to Treatment with Taxanes}

In 2007, a retrospective analysis of 1,500 women with nodepositive breast cancer showed that amplification of HER2 was associated with enhanced clinical benefit from the addition of paclitaxel after adjuvant treatment with doxorubicin [23]. The clinical evidence [24] is in conflict with a number of preclinical studies indicating that HER2-positive cancer is mostly resistant to taxanes. When cell culture tests were aimed at assessing proliferation rate/apoptosis, the results indicated an inverse correlation between HER2 and the outcome of taxane treatment.

The taxanes in clinical use (paclitaxel, docetaxel) stabilize tubulin polymers by directly attaching to tubulin and inhibit the dynamic assembly/disassembly of microtubules. In vitro, HER2 overexpression confers increased resistance to paclitaxel in breast cancer cells, while HER2 degradation increases docetaxel-induced apoptosis (for review see [25]; the patients reported in the analysis by Hayes et al. [23] had not received therapeutics interfering with HER2). While a few mechanisms have been suggested, taxane resistance has been mainly attributed to the presence of drug efflux pumps in breast cancer cells, which are the mdr-1-encoded P-glycoprotein (p170mdr1) and the ABCC3 gene product [26].

\section{Heightened Sensitivity to Taxane Treatment of HER2- Positive Breast Cancer}

By contrast, it is unclear how breast cancer positive for HER2 can be more sensitive to the effect of taxanes than HER2-negative tumors. The discrepancy may be in accordance with the notion that breast cancer - even relatively well-defined sub- types such as HER2-positive breast cancer - harbors significant genetic heterogeneity. The heterogeneity is reflected in the clinical analysis; a significant fraction of women with HER2-positive tumors failed to show a survival benefit, suggesting that a proportion of the tumors were resistant to paclitaxel.

We considered the fact that inhibition of microtubules may damage other functions than mitotic spindle formation (in general, microtubules are important in positioning intracellular membranous structures) to explain increased taxane sensitivity in HER2-overexpressing breast cancer. It may be suggested - based on the following findings - that taxanes specifically block tumor invasiveness: i) the invasiveness of breast cancer cells is enhanced by HER2-overexpression [27]; the invasive potential can be traced back by genetic engineering to a link between HER2 and the cellular ability to form microtubular structures [28]; ii) in principle, a cancer cell becomes resistant to taxanes if microtubule formation is less stable an event; conversely, restoring microtubule stability confers taxane sensitivity [29]; iii) while obviously necessary, the ability of HER2 to coordinate microtubule assembly however is not sufficient to account for malignant invasiveness; the invasive potential may be variable depending on the expression level of the GAB2 adaptor protein; overexpression of GAB2 in HER2-positive breast cancer cells is predictive of invasiveness [30]; iv) microarray analyses identified GAB2 within a group of genes whose expression was correlated to lymph node involvement in breast cancer patients [31]. Based on the current evidence, GAB2 expression in HER2-positive breast cancer may represent an additional independent pharmacogenomic marker for taxane sensitivity whereas P-glycoprotein and $\mathrm{ABCC} 3$ efflux pumps would indicate resistance. Establishing these as well as related genetic signatures requires additional prospective randomized trials.

\section{References}

1 Canfell K, Banks E, Moa AM, Beral V: Decrease in breast cancer incidence following a rapid fall in use of hormone replacement therapy in Australia. Med J Aust 2008;188:641-644.

2 Perou CM, Sørlie T, Eisen MB, van de Rijn M, Jeffrey SS, Rees CA, Pollack JR, Ross DT, Johnsen H, Akslen LA, et al.: Molecular portraits of human breast tumours. Nature 2000;406:747-752.

3 Lucena MI, Andrade RJ, Vicioso L, González FJ, Pachkoria K, García-Muñoz B: Prolonged cholestasis after raloxifene and fenofibrate interaction: a case report. World J Gastroenterol 2006;12: 5244-5246.

4 Dalén P, Dahl ML, Ruiz MLB, Nordin J, Bertilsson L: 10-Hydroxylation of nortriptyline in white persons with $0,1,2,3$, and 13 functional CYP2D6 genes. Clin Pharmacol Ther 1998;63:444-452.

$\checkmark 5$ Goetz MP, Rae JM, Suman VJ, Safgren SL, Ames MM, Visscher DW, Reynolds C, Couch FJ, Lingle WL, Flockhart DA, et al.: Pharmacogenetics of tamoxifen biotransformation is associated with clinical outcomes of efficacy and hot flashes. J Clin Oncol 2005;23:9312-9318.
6 Schroth W, Antoniadou L, Fritz P, Schwab M, Muerdter T, Zanger UM, Simon W, Eichelbaum M, Brauch H: Breast cancer treatment outcome with adjuvant tamoxifen relative to patient CYP2D6 and CYP2C19 genotypes. J Clin Oncol 2007;25: 5187-5193.

7 Davis MP, Homsi J: The importance of cytochrome P450 monooxygenase CYP2D6 in palliative medicine. Support Care Cancer 2001;9:442-451.

8 Jordan VC, O'Malley BW: Selective estrogen-receptor modulators and antihormonal resistance in breast cancer. J Clin Oncol 2007;25:5815-5824.

9 Mundhenke C, Schem C, Jonat W: Adjuvant endocrine therapy in early postmenopausal breast cancer. Breast Care 2008;3:4-10.

10 Riggins RB, Schrecengost RS, Guerrero MS, Bouton AH: Pathways to tamoxifen resistance. Cancer Lett 2007;256:1-24.

11 Arpino G, Wiechmann L, Osborne CK, Schiff R: Crosstalk between the estrogen receptor and the HER tyrosine kinase receptor family: molecular mechanism and clinical implications for endocrine therapy resistance. Endocr Rev 2008;29:217-233.
12 Giltnane JM, Rydén L, Cregger M, Bendahl PO, Jirström K, Rimm DL: Quantitative measurement of epidermal growth factor receptor is a negative predictive factor for tamoxifen response in hormone receptor positive premenopausal breast cancer. J Clin Oncol 2007;25:3007-3014.

13 Jiang X, Ellison SJ, Alarid ET, Shapiro DJ: Interplay between the levels of estrogen and estrogen receptor controls the level of the granzyme inhibitor, proteinase inhibitor 9 and susceptibility to immune surveillance by natural killer cells. Oncogene 2007;26:4106-4114.

14 Yen L, Benlimame N, Nie ZR, Xiao D, Wang T, Al Moustafa AE, Esumi H, Milanini J, Hynes NE, Pages G, Alaoui-Jamali MA: Differential regulation of tumor angiogenesis by distinct ErbB homo- and heterodimers. Mol Biol Cell 2002;13:4029-4044.

$\checkmark 15$ Petit AM, Rak J, Hung MC, Rockwell P, Goldstein N, Fendly B, Kerbel RS: Neutralizing antibodies against epidermal growth factor and ErbB-2/neu receptor tyrosine kinases down-regulate vascular endothelial growth factor production by tumor cells in vitro and in vivo: angiogenic implications for signal transduction therapy of solid tumors. Am J Pathol 1997;151:1523-1530. 
16 Nieto Y, Woods J, Nawaz F, Baron A, Jones RB, Shpall EJ, Nawaz S: Prognostic analysis of tumour angiogenesis, determined by microvessel density and expression of vascular endothelial growth factor, in high-risk primary breast cancer patients treated with high-dose chemotherapy. Br J Cancer 2007;97: 391-397.

17 Pietras RJ: Biologic basis of sequential and combination therapies for hormone-responsive breast cancer. Oncologist 2006;11:704-717.

18 Hyder SM, Nawaz Z, Chiappetta C, Stancel GM Identification of functional estrogen response elements in the gene coding for the potent angiogenic factor vascular endothelial growth factor. Cancer Res 2000;60:3183-3190.

19 Kristensen CA, Hamberg LM, Hunter GJ, Roberge S, Kierstead D, Wolf GL, Jain RK: Changes in vascularization of human breast cancer xenografts responding to antiestrogen therapy. Neoplasia 1999;1: 518-525.

20 Holmes CE, Huang JC, Pace TR, Howard AB, Muss HB: Tamoxifen and aromatase inhibitors differentially affect vascular endothelial growth factor and endostatin levels in women with breast cancer. Clin Cancer Res 2008;14:3070-3076.

21 Miller K, Wang M, Gralow J, Dickler M, Cobleigh M, Perez EA, Shenkier T, Cella D, Davidson NE: Paclitaxel plus bevacizumab versus paclitaxel alone for metastatic breast cancer. N Engl J Med 2007; 357:2666-2676.

22 Chen S, Masri S, Wang X, Phung S, Yuan YC, Wu X: What do we know about the mechanisms of aromatase inhibitor resistance? J Steroid Biochem Mol Biol 2006;102:232-240.

23 Hayes DF, Thor AD, Dressler LG, Weaver D, Edgerton S, Cowan D, et al.: HER2 and response to paclitaxel in node-positive breast cancer. N Engl J Med 2007;357:1496-1506.

24 Wenzel C, Steger GG: Adjuvant treatment of breast cancer with taxanes. Breast Care 2006;1 171-175.

25 Azambuja E, Durbecq V, Rosa DD, Colozza M, Larsimont D, Piccart-Gebhart M, Cardoso F: HER2 overexpression/amplification and its interaction with taxane-based therapy in breast cancer. Ann Oncol 2008;19:223-232.

26 O'Brien C, Cavet G, Pandita A, Hu X, Haydu L, Mohan S, Toy K, Rivers CS, Modrusan Z, Amler LC, Lackner MR: Functional genomics identifies ABCC3 as a mediator of taxane resistance in HER2-amplified breast cancer. Cancer Res 2008; 68:5380-5389.

-27 Roetger A, Merschjann A, Dittmar T, Jackisch C, Barnekow A, Brandt B: Selection of potentially metastatic subpopulations expressing c-erbB-2 from breast cancer tissue by use of an extravasation model. Am J Pathol 1998;153:1797-1806.

28 Marone R, Hess D, Dankort D, Muller WJ, Hynes NE, Badache A: Memo mediates ErbB2-driven cell motility. Nat Cell Biol 2004;6:515-522.

$\checkmark 29$ Ahmed AA, Mills AD, Ibrahim AE, Temple J, Blenkiron C, Vias M, Massie CE, Iyer NG, McGeoch A, Crawford R, et al.: The extracellular matrix protein TGFBI induces microtubule stabilization and sensitizes ovarian cancers to paclitaxel. Cancer Cell 2007;12:514-527.
30 Bentires-Alj M, Gil SG, Chan R, Wang ZC, Wang Y, Imanaka N, Harris LN, Richardson A, Neel BG, $\mathrm{Gu} \mathrm{H}$ : A role for the scaffolding adapter GAB2 in breast cancer. Nat Med 2006;12:114-121.

31 Huang E, Cheng SH, Dressman H, Pittman J, Tsou MH, Horng CF, Bild A, Iversen ES, Liao M, Chen CM, West M, Nevins JR, Huang AT: Gene expression predictors of breast cancer outcomes. Lancet 2003;361:1590-1596.

- 32 Timm R, Kaiser R, Lötsch J, Heider U, Sezer O, Weisz K, Montemurro M, Roots I, Cascorbi I: Association of cyclophosphamide pharmacokinetics to polymorphic cytochrome P450 2C19. Pharmacogenomics J 2005;5:365-373.

33 Ekhart C, Doodeman VD, Rodenhuis S, Smits PH, Beijnen JH, Huitema AD: Influence of polymorphisms of drug metabolizing enzymes (CYP2B6, CYP2C9, CYP2C19, CYP3A4, CYP3A5, GSTA1, GSTP1, ALDH1A1 and ALDH3A1) on the pharmacokinetics of cyclophosphamide and 4hydroxycyclophosphamide. Pharmacogenet. Genomics 2008;18:515-523.

34 De Jonge ME, Huitema AD, Holtkamp MJ, van Dam SM, Beijnen JH, Rodenhuis S: Aprepitant inhibits cyclophosphamide bioactivation and thiotepa metabolism. Cancer Chemother Pharmacol 2005; 56:370-378.

35 Mishra PJ, Humeniuk R, Mishra PJ, Longo-Sorbello GS, Banerjee D, Bertino JR: A miR-24 microRNA binding-site polymorphism in dihydrofolate reductase gene leads to methotrexate resistance. Proc Natl Acad Sci USA 2007;104:13513-13518.

36 Dulucq S, St-Onge G, Gagné V, Ansari M, Sinnett D, Labuda D, Moghrabi A, Krajinovic M: DNA variants in the dihydrofolate reductase gene and outcome in childhood ALL. Blood 2008;111: 3692-3700.

37 Zhang W, Press OA, Haiman CA, Yang DY, Gordon MA, Fazzone W, El-Khoueiry A, Iqbal S, Sherrod AE, Lurje G, Lenz HJ: Association of methylenetetrahydrofolate reductase gene polymorphisms and sex-specific survival in patients with metastatic colon cancer. J Clin Oncol 2007;25:3726-3731.

38 Ezzeldin HH, Diasio RB: Predicting fluorouracil toxicity: can we finally do it? J Clin Oncol 2008;26: 2080-2082.

39 Okuda H, Ogura K, Kato A, Takubo H, Watabe T: A possible mechanism of eighteen patient deaths caused by interactions of sorivudine, a new antiviral drug, with oral 5-fluorouracil prodrugs. J Pharmacol Exp Ther 1998;287:791-799.

40 Marsh S, Paul J, King CR, Gifford G, McLeod HL, Brown R: Pharmacogenetic assessment of toxicity and outcome after platinum plus taxane chemotherapy in ovarian cancer: the Scottish Randomised Trial in Ovarian Cancer. J Clin Oncol 2007;25: 4528-4535.

41 Henningsson A, Marsh S, Loos WJ, Karlsson MO, Garsa A, Mross K, Mielke S, Viganò L, Locatelli A, Verweij J, Sparreboom A, McLeod HL: Association of CYP2C8, CYP3A4, CYP3A5, and ABCB1 polymorphisms with the pharmacokinetics of paclitaxel. Clin Cancer Res 2005;11:8097-8104.

42 Marsh S, Somlo G, Li X, Frankel P, King CR, Shannon WD, McLeod HL, Synold TW: Pharmacogenetic analysis of paclitaxel transport and metabolism genes in breast cancer. Pharmacogenomics $\mathrm{J}$ 2007;7:362-365.
43 Smith NF, Marsh S, Scott-Horton TJ, Hamada A, Mielke S, Mross K, Figg WD, Verweij J, McLeod HL, Sparreboom A: Variants in the SLCO1B3 gene: interethnic distribution and association with paclitaxel pharmacokinetics. Clin Pharmacol Ther 2007;81:76-82.

44 Fagerholm R, Hofstetter B, Tommiska J, Aaltonen K, Vrtel R, Syrjäkoski K, Kallioniemi A, Kilpivaara O, Mannermaa A, Kosma VM, et al.: NAD(P) $\mathrm{H}$ :quinone oxidoreductase $1 \mathrm{NQO} 1 * 2$ genotype (P187S) is a strong prognostic and predictive factor in breast cancer. Nat Genet 2008;40: 844-853.

45 Wojnowski L, Kulle B, Schirmer M, Schlüter G, Schmidt A, Rosenberger A, Vonhof S, Bickeböller $\mathrm{H}$, Toliat MR, Suk EK, et al.: NAD(P)H oxidase and multidrug resistance protein genetic polymorphisms are associated with doxorubicin-induced cardiotoxicity. Circulation 2005;112:3754-3762.

46 Jannuzzo MG, Poggesi I, Spinelli R, Rocchetti M, Cicioni P, Buchan P: The effects of degree of hepatic or renal impairment on the pharmacokinetics of exemestane in postmenopausal women. Cancer Chemother Pharmacol 2004;53:475-481.

47 Buzdar AU, Robertson JF, Eiermann W, Nabholtz JM: An overview of the pharmacology and pharmacokinetics of the newer generation aromatase inhibitors anastrozole, letrozole, and exemestane. Cancer 2002;95:2006-2016.

48 Grimm SW, Dyroff MC: Inhibition of human drug metabolizing cytochromes $\mathrm{P} 450$ by anastrozole, a potent and selective inhibitor of aromatase. Drug Metable Dispos 1997;25:598-602.

49 Desta Z, Ward BA, Soukhova NV, Flockhart DA: Comprehensive evaluation of tamoxifen sequential biotransformation by the human cytochrome $\mathrm{P} 450$ system in vitro: prominent roles for CYP3A and CYP2D6. J Pharmacol Exp Ther 2004;310: 1062-1075.

50 Jeong EJ, Liu Y, Lin H, Hu M: Species- and disposition model-dependent metabolism of raloxifene in gut and liver: role of UGT1A10. Drug Metable Dispos 2005;33:785-794

51 Chen Q, Ngui JS, Doss GA, Wang RW, Cai X, DiNinno FP, Blizzard TA, Hammond ML, Stearns RA, Evans DC, Baillie TA, Tang W: Cytochrome P450 3A4-mediated bioactivation of raloxifene: irreversible enzyme inhibition and thiol adduct formation. Chem Res Toxicol 2002;15:907-914.

52 Robertson JF, Erikstein B, Osborne KC, Pippen J, Come SE, Parker LM, Gertler S, Harrison MP, Clarke DA: Pharmacokinetic profile of intramuscular fulvestrant in advanced breast cancer. Clin Pharmacokinet 2004;43:529-538.

53 Nakashima D, Takama H, Ogasawara Y, Kawakami T, Nishitoba T, Hoshi S, Uchida E, Tanaka H: Effect of cinacalcet hydrochloride, a new calcimimetic agent, on the pharmacokinetics of dextromethorphan: in vitro and clinical studies. J Clin Pharmacol 2007;47:1311-1319.

54 Abdel-Rahman SM, Marcucci K, Boge T, Gotschall RR, Kearns GL, Leeder JS: Potent inhibition of cytochrome P-450 2D6-mediated dextromethorphan O-demethylation by terbinafine. Drug Metable Dispos 1999;27:770-775.

55 Guzey C, Norstrom A, Spigset O: Change from the CYP2D6 extensive metabolizer to the poor metabolizer phenotype during treatment with bupropion. Ther Drug Monit 2002;24:436-437. 